\title{
Sources of volatility in stock returns in emerging markets
}

\section{Selçuk Caner \& Zeynep Önder}

To cite this article: Selçuk Caner \& Zeynep Önder (2005) Sources of volatility in stock returns in emerging markets, Applied Economics, 37:8, 929-941, DOI: 10.1080/00036840500061046

To link to this article: http://dx.doi.org/10.1080/00036840500061046

$$
\text { 册 Published online: } 22 \text { Aug } 2006 .
$$

Submit your article to this journal

Џlll Article views: 139

Q View related articles $\square$

Citing articles: 9 View citing articles 단 


\title{
Sources of volatility in stock returns in emerging markets
}

\author{
Selçuk Caner and Zeynep Önder* \\ Bilkent University, Faculty of Business Administration, \\ Bilkent, Ankara 06800, Turkey
}

In this study, the short-term fluctuations in the monthly returns on composite indexes of 17 emerging markets affected by the financial crises in the late 1990s and 2000 are decomposed with vector autoregressive estimates. The results are compared to the behaviour of variation in returns in developed markets. Three different models are estimated for each market. Due to first order autocorrelations, lagged returns contribute significantly to return volatility in emerging markets. Decomposition of variances indicates that dividend yield and interest rate are determining factors of volatility, but at varying degrees in different emerging markets. However, the role of dividend yield is not as strong as it is in the developed markets as efficient markets hypothesis would imply. In some cases, exchange rates significantly influence market volatility. Fluctuations in the world portfolio return have a small effect on return volatility in national markets. However, there are significant differences across all emerging markets that point to differences in market structures and particular conditions in each country. Significant contributions of interest rates, exchange rates and inflation imply the role of monetary and fiscal policy as precedents of financial crises.

\section{Introduction}

A large body of literature exists on the factors that explain the sources of fluctuations in stock returns (e.g., Chen et al., 1986; Campbell, 1987, 1991; Campbell and Shiller, 1988; Fama and French, 1988). These studies have shown that dividend yields and short-term interest rates partly explain the fluctuations in asset returns. In emerging markets, returns have higher volatility than the developed markets as shown by Bekaert and Harvey (1995, 1997) and Harvey (1995). In addition, De Santis and Imrahoroglu (1997) find that the risk in emerging markets is not priced except in Latin America. But, they find persistence and predictability in emerging markets not significantly different than in developed markets. The sources of return volatility in emerging markets are similar to those of the developed markets. Nonetheless, the contributions of the factors on return volatility vary from one country to another. Furthermore, they differ at different times as Chakrabarti and Roll (2000) observe increased correlation between the South East Asian markets and the European markets before the crisis. However, the correlation declined during and after the crisis.

Bekaert and Harvey (1997) attribute increases in volatility in emerging markets to world market integration defined as co-movements with developed markets. They also report reduction in volatility after capital market reforms. In addition, they identify asset concentration ratios, stock market development and economic integration, microstructure

\footnotetext{
*Corresponding author. E-mail: zonder@bilkent.edu.tr.
} 
effects and macroeconomic influences and political risks as factors that contribute to returns volatility. However, these factors do not have any theoretical foundation. Furthermore, monetary policy as defined by interest rates and the exchange rate policies have significant impacts on market volatility. Overvalued exchange rates as in the case of the Russian Federation or high real interest rates as in the case of Turkey can trigger crisis in financial markets. Currency crisis is often cited as a major factor that contributes to the collapse of financial markets in emerging countries. Higher volatility observed in these markets implies higher costs of capital. Therefore, by identifying appropriate factors of volatility and measuring their relative contributions to volatility, one can formulate policies to reduce such volatility due to interest rate regimes or exchange rate policies, a result often intended by market reforms.

In this study, to determine the factors that explain the sources of fluctuations in stock returns, a modified version of the consumption-based Capital Asset Pricing Model (CCAPM) is applied to account for additional risks in the evaluation of volatility of stock returns in emerging markets. In the basic formulation, expected stock returns are linearly related to contemporaneous consumption growth, a proportionality factor between the value of market portfolio and consumption and an additional term that reflects a premium on changes in interest rates. Further, the model is expanded to include the effect of exchange rate fluctuations on stock returns. ${ }^{1}$ The standard CCAPM has to be modified since markets function differently in emerging markets often characterized by random shocks to the consumption growth process while consumption is smoother in developed markets. Furthermore, foreign currency is often a close substitute for equity in emerging markets. These additional factors allow for the transmission of the effects of fiscal and monetary policies in developing countries that trigger the emerging market crises and they have to be included as factors of market volatility.

Seventeen emerging markets were chosen. The selection of countries is different than the countries included in most other studies on emerging markets. ${ }^{2}$ The purpose of this selection was to determine the sources of return fluctuations in emerging markets that were recently impacted by the worldwide financial crises, first, the crisis in the South East Asian countries in 1997, the crisis in Russia in 1998, followed by those in Brazil, Turkey and Argentina in 2000. So, the study estimates the sources of fluctuations in stock returns in major emerging markets that were recently impacted by various forms of financial crises. This study improves upon previous studies in understanding the sources of variability of stock returns in emerging markets by incorporating additional factors of volatility. These factors can be classified as fundamental variables, market conditions and external factors.

The sources of short-term fluctuations in returns on the national stock market composite indexes are decomposed using a vector autoregressive (VAR) model. The contribution of fundamental variables are estimated including dividend yield and interest rates to return volatility as well as other factors, such as the exchange rate and the inflation rate in emerging markets. Since fluctuations in some of these factors are induced by government policy, the contributions of these factors to return volatility may be viewed as the indirect impact of government policies in emerging financial markets.

Similar to developed financial markets, estimated factor contributions to variances of returns on national stock market indexes demonstrate that dividend yield contributes most to return volatility in emerging markets. However, there is a significant difference between emerging markets and developed markets in terms of contributions of dividend yield to market volatility. The dividend effect is much stronger in developed markets as one would expect from efficient markets. The effect of dividend yield changes diminishes significantly in emerging markets at varying degrees. The less the market is developed, the smaller is the contribution of the dividend yield to return volatility. This is particularly true for the countries in transition. On average, the contributions of inflation rate, real interest rate and exchange rate on the volatility of stock returns are found to be small but there is a wide range across the sampled markets thus, indicating the influence of local conditions in each country such as the monetary and fiscal policies of the countries.

The remainder of this paper is organized as follows. Section II provides the VAR model used for estimating the coefficients used in forecasting the returns and decomposition of returns variances,

\footnotetext{
${ }^{1}$ The derivation of the model is available from the authors upon request. The model used is an extension of the asset pricing model developed for an exchange economy in Lucas (1978) and Caner and Önder (1998).

${ }^{2}$ For example, see, Harvey et al. (2002), Korajczyki (1996) or Harvey (1995), to cite a few.
} 
the methodology is described in Section III, while the results of the VAR model are presented in Section IV. Section V concludes with a brief summary and remarks.

\section{Model Estimation and the Decomposition of Returns Volatility}

Using the modified CCAPM, the expected rate of return on stock market portfolio can be derived as follows:

$$
E\left[\frac{d a}{a}\right]=\left(\mu+\frac{1}{k}+\frac{1}{2} \frac{k_{r r}}{k} s^{2}+\frac{1}{2} \frac{k_{e e}}{k} \sigma_{e}^{2}\right) d t
$$

where the expected rate of return on the stock market portfolio is the sum of the mean consumption growth $(\mu)$, the inverse of the proportionality factor between the price and consumption $(1 / k)$ and the interest rate $(r)$ risk and the exchange rate risk $\left(\sigma_{e}\right) .{ }^{3}$ The first term on the RHS is the mean consumption growth rate. The second term is a proportionality factor while the third and fourth terms are adjustments for the additional premiums required to compensate for the uncertainty induced by the stochastic interest rate $r$ and the stochastic exchange rate $e$, respectively. ${ }^{4,5}$

In addition, using the expression for the expected rate of return, the variance of the rate of return on the stock market portfolio is calculated as follows:

$$
\begin{aligned}
\operatorname{Var}\left(\frac{d a}{a}\right) & =\left(\sigma^{2}+\frac{1}{k} k_{r} s^{2}+\frac{1}{k} k_{e} \sigma_{e}^{2}\right) d t \\
& =\sigma^{2}+\varepsilon_{r}^{2} s^{2}+\varepsilon_{e}^{2} \sigma_{e}^{2}
\end{aligned}
$$

The two terms inside the parentheses in addition to the variance of consumption growth $\left(\sigma^{2}\right)$ represent the contributions to returns risk by the stochastic interest rate and exchange rate processes and are positive. Thus, introduction of a stochastic interest rate and an exchange rate explicitly in the model results in properly accounting for the sources of volatility in the stock market returns. The second term $\left(\varepsilon_{r}^{2} s^{2}\right)$ represents the amount of additional risk due to interest rates. The third term $\left(\varepsilon_{e}^{2} s^{2}\right)$ is the amount of additional risk due to exchange rate fluctuations. The elasticity, $\varepsilon_{r}$, is the interest rate elasticity of the price of the stock market portfolio and $s^{2}$ is the variance of the stochastic drift of consumption growth. The second elasticity, $\varepsilon_{e}$, is the exchange rate elasticity of the price of the stock market portfolio and $\sigma_{e}^{2}$ is the variance of the exchange rate.

\section{Methodology}

In order to estimate the sources of variation in the stock market returns expressed in Equation 2, a VAR model of stock market returns is used. The model includes the yield on the three-month Treasury bill as a proxy for the short-term interest rate, dividend yield as a proxy for consumption growth (Breeden et al., 1989; Campbell and Mankiw, 1989; Mankiw and Zeldes, 1991), percentage change in the exchange rate and the inflation rate as explanatory factors. ${ }^{6}$ Because consumption data is at best available on a quarterly basis it is not possible to use it for monthly return estimations. However, dividend yield would be highly correlated with consumption in the context of an exchange economy. Although the expression for the variance of the stock market returns in Equation 2 is compact in the variances of consumption growth, the interest rate elasticity and the exchange rate elasticity, to be consistent with previous studies (eg. Fama and French, 1988; Campbell and Shiller, 1988; Campbell, 1991), the study includes inflation rate and the return on the world market to measure the effects of extended factors on the variance of the stock market returns implied by the model in the estimations. These are variables often cited as factors that precipitated the South East Asian crisis. For example, Chowdhry and Goyal (2000) identify exchange rates, inflation rate differentials, current account balances and increase in domestic credit levels as sources of the South East Asian crisis. However, they point out that not all factors contributed similarly in each and every country before and during the crisis.

\footnotetext{
${ }^{3}$ According to the CCAPM, price of the market portfolio is proportional to consumption and $k$ is the proportionality factor.

${ }^{4}$ In the standard CCAPM model the exogenous process is the consumption growth process. The expanded model used here adds the exchange rate as an exogenous stochastic process in addition to the stochastic consumption process. Exchange rate is a determining factor in emerging markets and foreign currencies are often used as a hedging asset. Both the consumption growth rate and the exchange rate are geometric Brownian motion. Furthermore, the drift term of the consumption process is also stochastic.

${ }^{5}$ In the model, the interest rate is also a stochastic process derived from the relationship $r=\mu+\rho-\sigma^{2}$. See, Caner and Önder (2000) and Long and Plosser (1983).

${ }^{6}$ The reasons for choosing a VAR model over a univariate time series model are explained in Campbell (1991). Since error terms would be correlated, a VAR model to estimate the factor contributions to volatility would be appropriate.
} 


\section{Sample and data}

The sample countries include 17 emerging markets and two developed markets. All the countries included as emerging markets are more or less at a different stage of financial market development with the possible exception of Hong Kong and Singapore. The selection of countries is different than the countries included in most other studies on emerging markets. ${ }^{7}$ The purpose of this selection was to determine the sources of return fluctuations in emerging markets that were recently impacted by the worldwide financial crises. That is, the crisis in the South East Asian countries followed by the crises in Russia and then in Brazil, Turkey and Argentina establishes the rationale for focusing on these economies.

Return on the 19 national equity markets are calculated from Morgan Stanley Capital International (MSCI) stock market indexes ${ }^{8}$ obtained from the Datastream Research Service. The list of countries considered is included in Table 1. The sample includes four Latin American markets (Argentina, Brazil, Chile and Mexico), five Eastern European markets (Czech Republic, Hungary, Poland, Russia and Turkey) and eight Asian markets (Hong Kong, Indonesia, Korea, Malaysia, Philippines, Singapore, Taiwan and Thailand). The USA and Japan are also included as developed markets as benchmark countries for comparison purposes. The sample period changes in each market because of the availability of the stock market index and the other variables used in the estimations.

Summary statistics of the market returns in terms of local currency are presented in Table 2 for the period covered in the analysis. The statistics include the average monthly returns, standard deviations, skewness, kurtosis and first order autocorrelations. Monthly returns are calculated by compounding daily returns. The mean returns and unconditional volatility of returns are higher in the Latin American and Eastern European markets than the Asian markets in the sample. Volatility of returns in all emerging country indexes is at least twice the volatility of the return on the world market portfolio except Chile and Singapore while only six emerging markets had higher returns than the world market returns. The correlation coefficients of stock market
Table 1. List of Countries

\begin{tabular}{lll}
\hline & Country & Period covered \\
\hline & Latin America & \\
1 & Argentina & $1991: 05-2001: 03$ \\
2 & Brazil & $1994: 11-2001: 03$ \\
3 & Chile & $1994: 02-2001: 03$ \\
4 & Mexico & $1994: 12-2001: 03$ \\
& Eastern Europe & \\
5 & Czech Republic & $1995: 02-2001: 03$ \\
6 & Hungary & $1995: 10-2001: 03$ \\
7 & Poland & $1993: 07-2001: 03$ \\
8 & Russia & $1995: 02-2001: 03$ \\
9 & Turkey & $1992: 03-2001: 03$ \\
& South East Asia & $1990: 03-2001: 03$ \\
10 & Hong Kong & $1989: 02-2001: 03$ \\
11 & Indonesia & $1993: 02-2001: 03$ \\
12 & Korea & $1993: 09-2000: 10$ \\
13 & Malaysia & $1988: 02-2001: 03$ \\
14 & Philippines & $1989: 03-2001: 03$ \\
15 & Singapore & $1992: 02-2001: 03$ \\
16 & Taiwan & $1992: 02-2001: 03$ \\
17 & Thailand & $1990: 03-2001: 03$ \\
18 & Developed Markets & $1985: 02-2001: 03$ \\
19 & Japan &
\end{tabular}

returns among the countries within each region vary significantly. So, regional markets do not necessarily move together. The average correlation between the returns in emerging markets in the sample and the world market return is $0.54 .^{9}$

The dividend yield and the yield on three-month T-bills in each market are obtained from the Datastream Research Service. If Datastream does not report the yield on Treasury bills in a particular country, the interest rate on three-month certificates of deposits or the three-month interbank rate is used. The only exception is Turkey where the data were obtained from the Istanbul Stock Exchange. The yield on the Turkish Treasury bills is calculated from the yield curve at the end of the month. All interest rate measures are monthly yields. Since inflation rate is included in the models as an explanatory variable, real interest rate is used in the estimations.

The exchange rate is the ratio of the US dollar per unit of the local currency. For the USA, the Federal Reserve's exchange rate index is used which

\footnotetext{
${ }^{7}$ For example, see, Harvey et al. (2002), Korajczyki (1996) or Harvey (1995), to cite a few.

${ }^{8}$ Bekeart and Harvey (1995) provide a summary of the MSCI methodology. MSCI indexes are value-weighted with a target of $60 \%$ coverage of total market capitalization of each market. The indices replicate the industrial composition of the local markets and the sample represents large, medium and small capitalization stocks excluding nondomiciled companies and investment funds.

${ }^{9} \mathrm{~A}$ table of correlations of returns between the markets can be provided upon request.
} 
Table 2. Descriptive statistics and autocorrelations of monthly returns

\begin{tabular}{|c|c|c|c|c|c|c|}
\hline Country & $\begin{array}{l}\text { Mean } \\
(\%)\end{array}$ & $\begin{array}{l}\text { Standard } \\
\text { deviation } \\
(\%)\end{array}$ & Skewness & Kurtosis & $\begin{array}{l}\text { First-order } \\
\text { serial correlation }\end{array}$ & $\begin{array}{l}\text { Correlation with } \\
\text { return on world } \\
\text { index }\end{array}$ \\
\hline \multicolumn{7}{|l|}{ Latin America } \\
\hline Argentina & 0.28 & 10.20 & -0.5535 & 4.5774 & 0.009 & 0.58 \\
\hline Brazil & 1.02 & 10.94 & -1.2997 & 7.0791 & -0.113 & 0.70 \\
\hline Chile & 0.20 & 6.88 & -1.0556 & 7.9237 & -0.049 & 0.58 \\
\hline Mexico & 1.07 & 9.13 & -0.7180 & 3.9416 & -0.105 & 0.64 \\
\hline \multicolumn{7}{|l|}{ Eastern Europe } \\
\hline Czech Republic & -0.04 & 8.79 & -0.3361 & 3.9010 & -0.028 & 0.29 \\
\hline Hungary & 2.27 & 12.53 & -0.3121 & 5.9546 & -0.002 & 0.58 \\
\hline Poland & -0.62 & 12.72 & -0.2793 & 4.0777 & 0.046 & 0.48 \\
\hline Russia & 0.70 & 23.81 & -0.7164 & 4.5617 & 0.132 & 0.56 \\
\hline Turkey & 4.69 & 16.37 & 0.0774 & 4.2920 & 0.074 & 0.37 \\
\hline \multicolumn{7}{|l|}{ South East Asia } \\
\hline Hong Kong & 0.91 & 8.59 & -0.1434 & 4.9329 & 0.038 & 0.59 \\
\hline Indonesia & -0.60 & 11.82 & -0.4127 & 5.3570 & 0.075 & 0.62 \\
\hline Korea & 0.15 & 11.00 & 0.6203 & 5.0461 & 0.168 & 0.39 \\
\hline Malaysia & 1.09 & 8.91 & 0.0896 & 4.8316 & 0.083 & 0.51 \\
\hline Philippines & 0.75 & 8.97 & 0.0391 & 4.2794 & 0.131 & 0.62 \\
\hline Singapore & 0.28 & 7.08 & -0.3080 & 4.4737 & 0.010 & 0.62 \\
\hline Taiwan & 0.20 & 9.20 & 0.9613 & 4.9744 & 0.033 & 0.47 \\
\hline Thailand & -0.72 & 12.36 & 0.1789 & 3.5885 & -0.025 & 0.57 \\
\hline \multicolumn{7}{|c|}{ Developed Markets } \\
\hline Japan & -0.43 & 6.24 & -0.2078 & 3.8517 & 0.010 & 0.67 \\
\hline USA & 1.00 & 4.50 & -1.2275 & 7.7203 & -0.015 & 0.91 \\
\hline World & 0.78 & 4.14 & -1.3794 & 7.9957 & 0.057 & 1.00 \\
\hline
\end{tabular}

Note: Monthly average returns are calculated using daily returns on each national market index and the world market portfolio constructed by MSCI. Standard deviations are calculated using daily returns and monthly average returns on the national market portfolios. Returns are ex-dividend.

is a basket of currencies of its major trading partners. The inflation rate is based on the wholesale price index in all markets except for Hong Kong where Datastream does not report the wholesale price index. Since the consumption data are available on a quarterly basis at best, the consumption growth rate is approximated by the monthly dividend yield. ${ }^{10}$

\section{The VAR model}

Three models are estimated to identify the sources of variability in stock returns. ${ }^{11}$ In the first model which is the basic VAR model six variables are included: the stock market return, the real yield on three-month Treasury bill, the dividend yield, the inflation rate and the exchange rate. The following basic VAR model of the general form is estimated:

$$
\begin{aligned}
X_{t}= & A X_{t-1}+\varepsilon_{t} \\
X_{t}= & {\left[\begin{array}{l}
\text { Return on the Index } \\
\text { Real Interest Rate } \\
\text { Dividend Yield } \\
\text { Inflation Rate } \\
\text { Exchange Rate }
\end{array}\right] }
\end{aligned}
$$

In the above expression dividend yield is used as a proxy for the consumption growth process. The second model includes return on the world market index in addition to all the variables included in the first model. The third model is the second model without the exchange rate.

\footnotetext{
${ }^{10}$ The change in dividend yield has a higher correlation with consumption growth than the GDP growth rate at lower frequencies. Therefore, dividend yield is a better proxy for consumption growth than the GDP growth rate. Nevertheless, the model is also estimated by using growth rate of GDP and the growth rate in industrial production as proxies for consumption growth. Similar to Chowdhry and Goyal (2000), it is found that the GDP growth rate had a minor impact on returns volatility, about $2.9 \%$ on average with the exception of the Russian Federation where it is $22 \%$.

${ }^{11}$ Model estimates are provided in Tables 4-6.
} 
Table 3. Summary statistics, means and standard deviations of factors of returns variances ${ }^{1}$

\begin{tabular}{|c|c|c|c|c|c|}
\hline Country & $\begin{array}{l}\text { Exchange rate } \\
\text { (\% change) }\end{array}$ & $\begin{array}{l}\text { Dividend } \\
\text { yield }(\%)\end{array}$ & $\begin{array}{l}\text { Inflation } \\
\text { rate }(\%)\end{array}$ & $\begin{array}{l}\text { Stock market } \\
\text { return }(\%)\end{array}$ & $\begin{array}{l}\text { Real interest } \\
\text { Rate }(\%)\end{array}$ \\
\hline \multicolumn{6}{|l|}{ Latin America } \\
\hline \multirow{2}{*}{ Argentina } & 0.01 & 3.49 & 0.06 & 0.28 & 0.81 \\
\hline & 0.11 & 0.76 & 0.78 & 10.20 & 0.88 \\
\hline \multirow[t]{2}{*}{ Brazil } & 1.19 & 2.55 & 0.83 & 1.02 & 1.28 \\
\hline & 6.58 & 2.30 & 1.22 & 10.94 & 1.44 \\
\hline \multirow[t]{2}{*}{ Chile } & 0.41 & 2.80 & 0.47 & 0.20 & 0.06 \\
\hline & 1.78 & 0.39 & 0.96 & 6.88 & 0.99 \\
\hline \multirow[t]{2}{*}{ Mexico } & 1.32 & 1.42 & 1.58 & 1.07 & 0.66 \\
\hline & 5.60 & 0.31 & 0.80 & 9.13 & 0.87 \\
\hline \multicolumn{6}{|l|}{ Eastern Europe } \\
\hline \multirow[t]{2}{*}{ Czech Republic } & 0.43 & 2.19 & 0.38 & -0.04 & 0.44 \\
\hline & 3.36 & 0.43 & 0.47 & 8.79 & 0.56 \\
\hline \multirow{2}{*}{ Hungary } & 1.24 & 2.67 & 1.01 & 2.27 & 0.38 \\
\hline & 2.27 & 1.56 & 0.82 & 12.53 & 0.76 \\
\hline \multirow[t]{2}{*}{ Poland } & 0.73 & 1.10 & 0.90 & -0.62 & 0.74 \\
\hline & 2.47 & 0.53 & 0.83 & 12.72 & 0.69 \\
\hline \multirow[t]{2}{*}{ Russia $^{2}$} & 2.79 & 63.35 & 3.27 & 0.70 & 0.31 \\
\hline & 8.24 & 111.14 & 3.84 & 23.81 & 2.80 \\
\hline \multirow[t]{2}{*}{ Turkey } & 4.75 & 4.50 & 4.35 & 4.69 & 1.61 \\
\hline & 5.68 & 2.57 & 2.75 & 16.37 & 2.09 \\
\hline \multicolumn{6}{|l|}{ South East Asia } \\
\hline \multirow[t]{2}{*}{ Hong Kong } & 0.00 & 3.37 & 0.40 & 0.91 & 0.09 \\
\hline & 0.12 & 0.92 & 0.67 & 8.59 & 0.70 \\
\hline \multirow[t]{2}{*}{ Indonesia } & 1.33 & 1.48 & 1.16 & -0.60 & 0.33 \\
\hline & 10.22 & 0.61 & 3.41 & 11.82 & 3.04 \\
\hline \multirow[t]{2}{*}{ Korea } & 0.52 & 1.60 & 0.30 & 0.15 & 0.64 \\
\hline & 4.47 & 0.55 & 0.88 & 11.00 & 0.77 \\
\hline \multirow[t]{2}{*}{ Malaysia } & 0.45 & 1.87 & 0.26 & 0.02 & 0.27 \\
\hline & 3.09 & 0.74 & 1.80 & 11.14 & 1.64 \\
\hline \multirow[t]{2}{*}{ Philippines } & 0.55 & 0.92 & 0.46 & 0.75 & 0.70 \\
\hline & 3.06 & 0.52 & 1.75 & 8.97 & 1.72 \\
\hline \multirow[t]{2}{*}{ Singapore } & -0.05 & 1.94 & -0.03 & 0.28 & 0.22 \\
\hline & 1.63 & 0.43 & 1.64 & 7.08 & 1.62 \\
\hline \multirow[t]{2}{*}{ Taiwan } & 0.25 & 1.31 & 0.06 & 0.20 & 0.49 \\
\hline & 1.67 & 0.40 & 0.85 & 9.20 & 0.85 \\
\hline \multirow[t]{2}{*}{ Thailand } & 0.52 & 2.31 & 0.28 & -0.72 & 0.55 \\
\hline & 4.35 & 1.28 & 1.03 & 12.36 & 1.00 \\
\hline \multicolumn{6}{|c|}{ Developed Markets } \\
\hline \multirow[t]{2}{*}{ Japan } & -0.12 & 0.77 & -0.06 & -0.43 & 0.24 \\
\hline & 3.56 & 0.12 & 0.24 & 6.24 & 0.29 \\
\hline \multirow[t]{2}{*}{ U.S. } & -0.12 & 2.66 & 0.14 & 1.00 & 0.31 \\
\hline & 2.13 & 0.98 & 0.60 & 4.50 & 0.60 \\
\hline
\end{tabular}

${ }^{1}$ For each market, the first row represents mean values and the second row represents standard deviations.

${ }^{2}$ Includes the period of hyperinflation.

Due to limited number of observations, the first-order VAR model is used. Furthermore, serial autocorrelations with order of more than one decline significantly. Autocorrelations in emerging markets are significantly larger than the autocorrelation of the return on the world market. The distribution of returns on national markets is non-normal with skewness and kurtosis values significantly different than zero.
Table 3 includes summary statistics of the variables used in estimating the VAR model. Correlations of the same variables for each country are reported in the Appendix. Mean monthly returns range from $-0.72 \%$ for Thailand to $4.69 \%$ for Turkey for the period considered. ${ }^{12}$ One country, Turkey, is marked with high inflation rates, high dividend yields and high real interest rates. The financial crises experienced in

\footnotetext{
${ }^{12}$ Between January 1998 and August 1998, the Russian equity market lost 80\% of its value. However, since then the market experienced significant returns albeit in a very restricted market.
} 


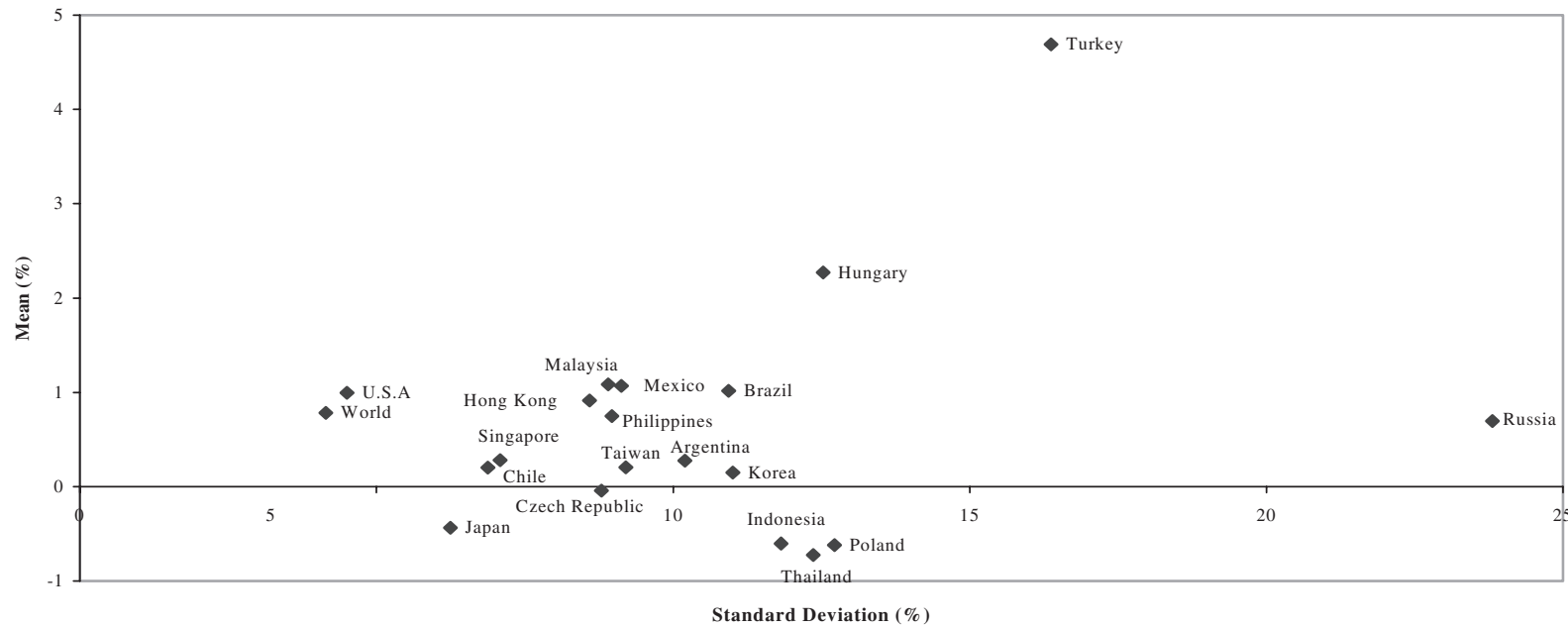

Fig. 1. Means and standard deviations of national market returns

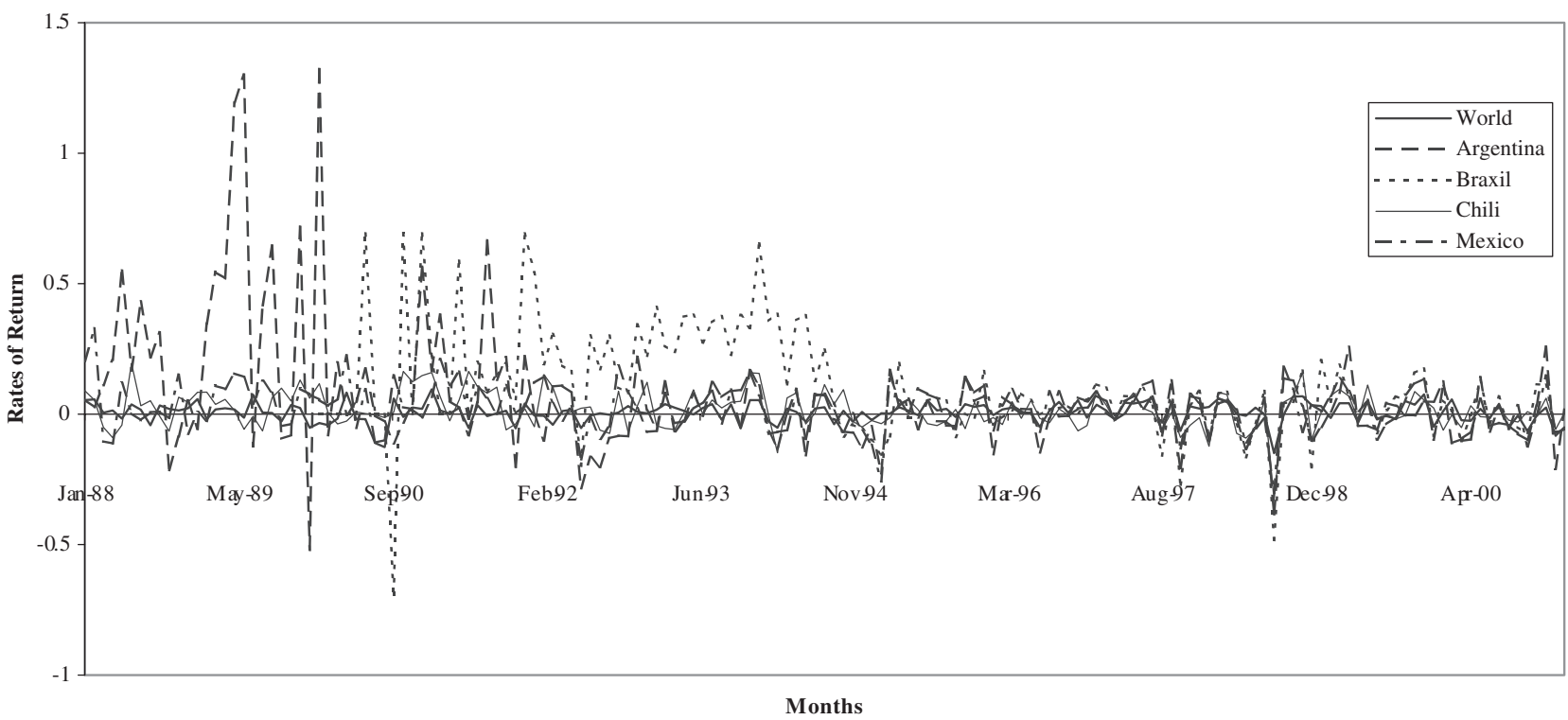

Fig. 2. Returns on Latin American countries

most of the countries considered in 1997 and 1998 resulted with high volatility in exchange rates, interest rates and stock market returns. Return risk relationship of all the countries in the sample is shown in Fig. 1. Figures 2 through 4 depict the fluctuations in the monthly returns by region.

Grouping the countries by region demonstrates varying volatility for different markets. A distinct pattern of high returns and volatility exists until the end of 1994, particularly, in Argentina and Brazil. However, Latin American countries experienced stable markets between 1994 and 1998 (Fig. 2). Eastern European countries are marked with continuous volatility since 1993 (Fig. 3). This points to some of the transition problems and incomplete market liberalization policies in financial markets in these countries. In Fig. 4, South East Asian countries except Indonesia demonstrate relatively stable markets for a long time and a sharp increase in volatility since 1997, after the South East Asian financial crisis.

\section{Estimation of Sources of Variance in Returns}

Three different VAR models were estimated and variances of stock market return were decomposed variances of stock market returns were estimated to determine the effects the interest rates, the 


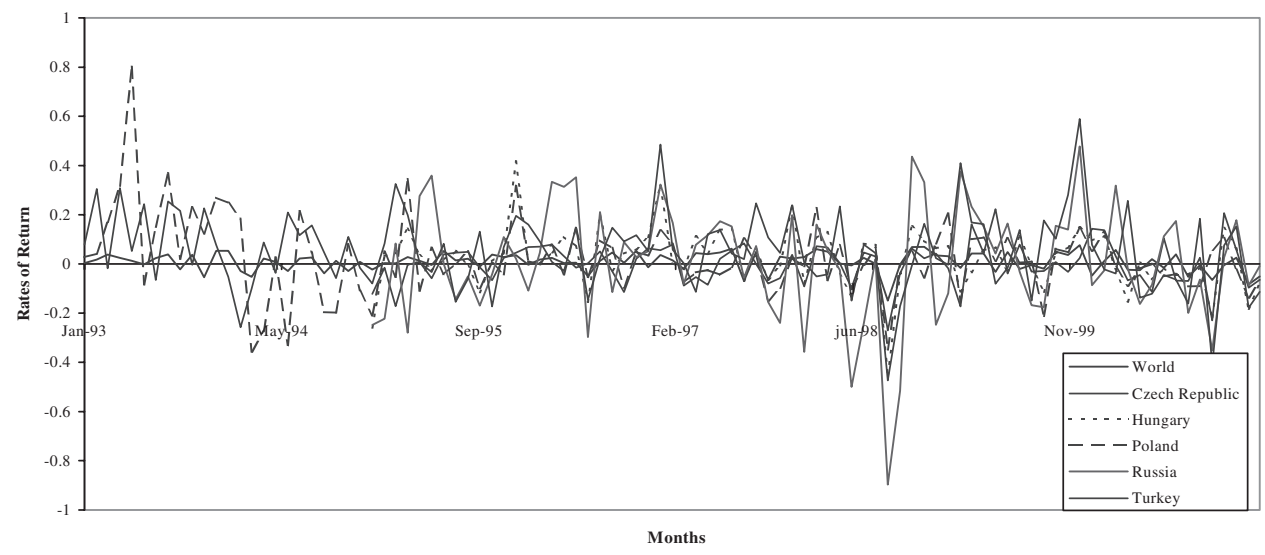

Fig. 3. Returns on Eastern European countries

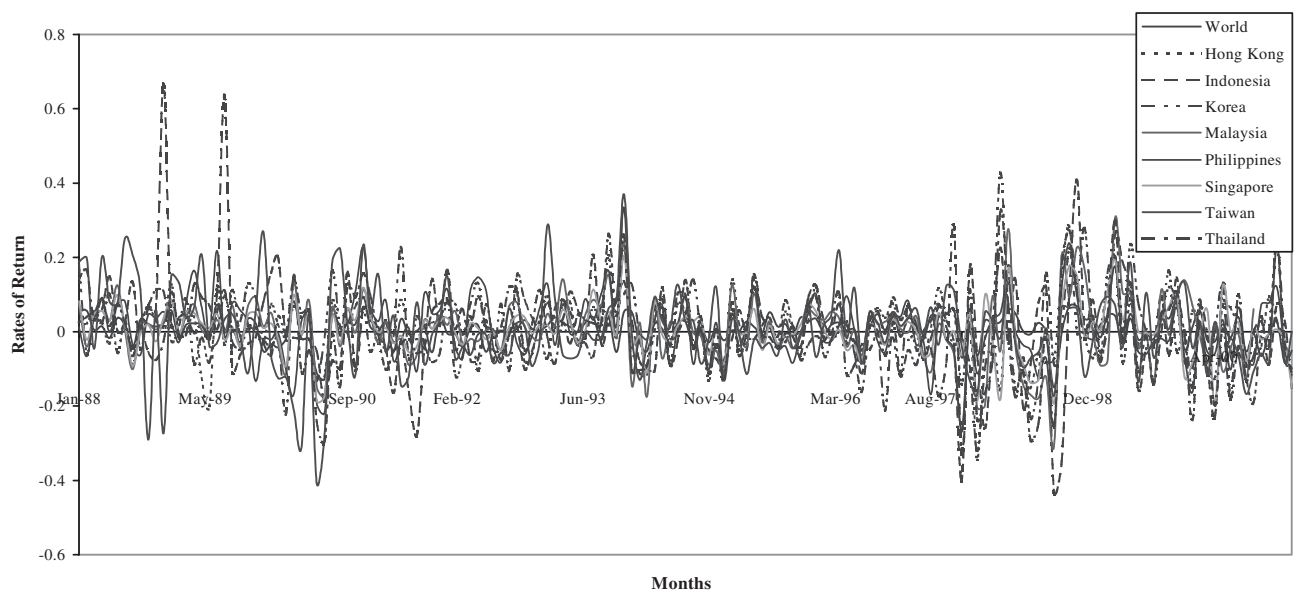

Fig. 4. Returns on Southeast Asian countries

exchange rate, inflation and the international market conditions. The decomposition of variances of returns obtained by using the three models on country stock market indexes is reported in Tables 4-6. Each model is estimated for all 17 emerging markets and the two developed markets. The tables include the share of factor loadings of each variable in the VAR estimates on the variances of stock market portfolio returns. Decomposition of return variances for Model I is included in Table 4. Estimates of Models II and III are included in Tables 5 and 6, respectively. All model results are robust in terms of the contributions of factors of volatility.

\section{Results of Model I}

On average, dividend yields account for $43 \%$ of returns volatility while lagged returns on the country index cause about $47 \%$ of the volatility in emerging markets. This contrasts with the contribution of dividend yield to return volatility of $84 \%$ and $93 \%$ for the USA and Japan, respectively. The high contribution of lagged stock returns implies the predictability of stock returns with past data and questions the efficiency of emerging markets. Dividend yield contribution to stock market return volatility is the highest in Hong Kong among the emerging market countries while it is the lowest in the Russian Federation and the Czech Republic. Dividend yield is a major fundamental variable in the model. The impact of this fundamental variable might be considered as an indicator of the stock market development since its impact is highest on the volatility of developed stock markets.

Real short-term interest rates explain about 3.7\% (unweighted) of the returns volatility on average while their effect on the return volatility in the Russian Federation and Hungary is $10 \%$. However, fluctuation in the real short-term interest rate is not a significant factor for Argentina, Indonesia, Korea, the Philippines and Taiwan. This may be due to the large government debt market in the Russian 
Table 4. Variance decomposition of monthly returns on msci composite index for sample countries - Model I

\begin{tabular}{|c|c|c|c|c|c|c|}
\hline Country & $\begin{array}{l}\text { Standard } \\
\text { error }\end{array}$ & $\begin{array}{l}\text { Dividend } \\
\text { yield }\end{array}$ & $\begin{array}{l}\text { Inflation } \\
\text { rate }\end{array}$ & $\begin{array}{l}\text { Real } \\
\text { interest } \\
\text { rate }\end{array}$ & $\begin{array}{l}\text { Exchange } \\
\text { rate }\end{array}$ & $\begin{array}{l}\text { Return on } \\
\text { national } \\
\text { MSCI index }\end{array}$ \\
\hline \multicolumn{6}{|l|}{ Emerging Markets } & \\
\hline Argentina & 0.1014 & 65.6223 & 6.8742 & 0.4368 & 0.9169 & 26.1499 \\
\hline Brazil & 0.1106 & 10.2686 & 7.0600 & 8.1608 & 5.5980 & 68.9125 \\
\hline Chile & 0.0667 & 45.6232 & 6.9249 & 4.1619 & 4.3199 & 38.9701 \\
\hline Mexico & 0.0917 & 51.3436 & 2.6186 & 2.4520 & 2.9638 & 40.6220 \\
\hline \multicolumn{7}{|l|}{ Eastern Europe } \\
\hline Czech Republic & 0.0867 & 5.0454 & 1.4595 & 3.7094 & 3.3873 & 86.3983 \\
\hline Hungary & 0.1234 & 22.3649 & 0.8169 & 9.8715 & 2.3869 & 64.5599 \\
\hline Poland & 0.1200 & 24.5550 & 0.7815 & 2.0335 & 3.2202 & 69.4098 \\
\hline Russia & 0.2342 & 4.8142 & 10.3209 & 10.4639 & 13.6680 & 60.7331 \\
\hline Turkey & 0.1747 & 55.3194 & 1.6156 & 5.8716 & 1.2579 & 35.9356 \\
\hline \multicolumn{7}{|l|}{ South East Asia } \\
\hline Hong Kong & 0.0855 & 81.4480 & 0.0380 & 2.1396 & 0.3161 & 16.0583 \\
\hline Indonesia & 0.1183 & 38.6210 & 2.4620 & 0.6972 & 2.4938 & 55.7260 \\
\hline Korea & 0.1109 & 54.9390 & 3.4315 & 1.1499 & 6.3337 & 34.1460 \\
\hline Malaysia & 0.1112 & 70.1481 & 5.4541 & 4.8233 & 2.6263 & 16.9482 \\
\hline Philippines & 0.0899 & 25.9071 & 1.6915 & 0.6500 & 1.7228 & 70.0287 \\
\hline Singapore & 0.0694 & 53.7064 & 0.3734 & 3.0327 & 2.5200 & 40.3676 \\
\hline Taiwan & 0.0917 & 71.3842 & 0.3130 & 0.6544 & 0.9394 & 26.7091 \\
\hline Thailand & 0.1233 & 52.6133 & 0.9638 & 3.4371 & 0.1657 & 42.8200 \\
\hline \multicolumn{7}{|l|}{ Developed Markets } \\
\hline Japan & 0.0608 & 93.1335 & 0.0364 & 0.2157 & 0.4896 & 6.1248 \\
\hline USA & 0.0448 & 84.0104 & 0.4285 & 0.1241 & 0.4091 & 15.0279 \\
\hline \multicolumn{7}{|l|}{ Average } \\
\hline Emerging Markets & & 43.1602 & 3.1294 & 3.7497 & 3.2257 & 46.7350 \\
\hline $\begin{array}{l}\text { Developed Markets } \\
\text { (Japan and the USA) }\end{array}$ & & 88.5720 & 0.2325 & 0.1699 & 0.4494 & 10.5764 \\
\hline
\end{tabular}

Note: Factor loadings for each factor are estimated using the VAR model.

Federation and Hungary. On the other hand, in countries where budget deficits are not large, interest rates do not affect market volatility.

Inflation rate is a significant factor for returns volatility in Russia, Argentina, Brazil, Chile and Malaysia. In Hong Kong inflation rate has the least impact on returns volatility among the emerging markets similar to the developed markets.

Exchange rate on average contributes $3.2 \%$ to return volatility. However, it can be as high as $14 \%$ in the Russian Federation where significant currency depreciation was experienced over the sample period. Exchange rate volatility is not a significant factor for returns volatility in Thailand, Hong Kong, Taiwan and Argentina. These countries have either fixed exchange rates or a crawling peg. Although exchange rate regime is often cited as a major factor that contributed to the collapse of domestic financial markets in South East Asian markets, according to Granger, Huang and Yang (GHY) (2000) exchange rates had a limited role in the crisis. Furthermore, the causality was both ways, for example, while exchange rate collapse had a negative impact on the stock prices in Thailand, Korea, Malaysia and the Philippines, it was the other way around in Hong Kong and the Philippines. Similar to GHY (2000), the estimates of the effect of the exchange rate on the volatility of the stock market returns are also small. However, contribution of exchange rates to return volatility is high in countries with floating exchange rate regimes such as Brazil, Chile and South Korea. Obviously, exchanges rate fluctuations are not a problem for countries that fixed their domestic currencies to another major currency (currency boards) with sufficient international reserves.

\section{Results of Model II}

Introducing the return on the world market index in Model II does not significantly alter the importance of return on the national index and the dividend yield. Lagged returns on the national market portfolio and dividend yields explain on average $46 \%$ and $42 \%$ of return volatility respectively. The results 
Table 5. Variance decomposition of monthly returns on MSCI composite index for sample countries - Model II

\begin{tabular}{|c|c|c|c|c|c|c|c|}
\hline Country & $\begin{array}{l}\text { Standard } \\
\text { error }\end{array}$ & $\begin{array}{l}\text { Dividend } \\
\text { yield }\end{array}$ & $\begin{array}{l}\text { Inflation } \\
\text { rate }\end{array}$ & $\begin{array}{l}\text { Real } \\
\text { interest } \\
\text { rate }\end{array}$ & $\begin{array}{l}\text { Exchange } \\
\text { rate }\end{array}$ & $\begin{array}{l}\text { Return on } \\
\text { national } \\
\text { MSCI index }\end{array}$ & $\begin{array}{l}\text { Return on } \\
\text { MSCI } \\
\text { world index }\end{array}$ \\
\hline \multicolumn{8}{|l|}{ Emerging Markets } \\
\hline Argentina & 0.1015 & 65.6153 & 6.9599 & 0.5571 & 0.8865 & 25.3001 & 0.6812 \\
\hline Brazil & 0.1104 & 9.9091 & 7.0916 & 8.3988 & 4.4521 & 69.0616 & 1.0868 \\
\hline Chile & 0.0667 & 45.3160 & 6.9080 & 4.2614 & 4.4916 & 38.6705 & 0.3526 \\
\hline Mexico & 0.0917 & 48.5045 & 2.2150 & 2.0183 & 2.9588 & 40.3752 & 3.9282 \\
\hline \multicolumn{8}{|l|}{ Eastern Europe } \\
\hline Czech Republic & 0.0867 & 4.7333 & 1.4337 & 3.7634 & 4.9545 & 83.4902 & 1.6248 \\
\hline Hungary & 0.1234 & 22.4524 & 0.6204 & 9.0700 & 2.4604 & 64.4331 & 0.9638 \\
\hline Poland & 0.1200 & 23.6407 & 0.8138 & 2.1064 & 3.3684 & 69.2252 & 0.8456 \\
\hline Russia & 0.2346 & 4.7341 & 8.6075 & 9.7576 & 13.0024 & 60.6313 & 3.2671 \\
\hline Turkey & 0.1748 & 52.4615 & 1.8729 & 6.0496 & 0.9997 & 36.0580 & 2.5584 \\
\hline \multicolumn{8}{|l|}{ South East Asia } \\
\hline Hong Kong & 0.0855 & 77.9605 & 0.0772 & 2.0347 & 0.4665 & 15.9393 & 3.5219 \\
\hline Indonesia & 0.1183 & 35.4938 & 2.2757 & 0.5021 & 3.5228 & 55.0973 & 3.1083 \\
\hline Korea & 0.1109 & 54.4988 & 3.1796 & 1.2875 & 6.2365 & 33.7424 & 1.0553 \\
\hline Malaysia & 0.1112 & 68.7352 & 5.4155 & 4.7394 & 2.7690 & 17.0123 & 1.3287 \\
\hline Philippines & 0.0899 & 26.0400 & 1.4626 & 0.6375 & 1.6346 & 69.5144 & 0.7110 \\
\hline Singapore & 0.0694 & 53.5315 & 0.4303 & 3.0805 & 2.3476 & 40.2976 & 0.3124 \\
\hline Taiwan & 0.0918 & 69.4510 & 0.3061 & 0.5567 & 0.8725 & 26.3128 & 2.5008 \\
\hline Thailand & 0.1233 & 51.7179 & 0.9962 & 3.7320 & 0.1704 & 42.6412 & 0.7423 \\
\hline \multicolumn{8}{|l|}{ Developed Markets } \\
\hline Japan & 0.0609 & 92.9510 & 0.0366 & 0.2220 & 0.5267 & 6.0641 & 0.1996 \\
\hline USA & 0.0448 & 83.9952 & 0.4317 & 0.1266 & 0.4078 & 15.0258 & 0.0129 \\
\hline \multicolumn{8}{|l|}{ Average } \\
\hline Emerging Markets & & 42.0468 & 2.9804 & 3.6796 & 3.2703 & 46.3413 & 1.6817 \\
\hline $\begin{array}{l}\text { Developed Markets } \\
\text { (Japan and the USA) }\end{array}$ & & 88.4731 & 0.2342 & 0.1743 & 0.4673 & 10.5450 & 0.1063 \\
\hline
\end{tabular}

Note: Model II includes all the variables in Model I and the return on the MSCI World Index to measure the effect of fluctuations in the international markets.

are tabulated in Table 5. On average, world market index accounts for about $1.7 \%$ of volatility in emerging markets. The average impact of the world market index on Japan and the USA is a low, $0.1 \%$. Contrary to claims, the fluctuations in the world market portfolio have negligible effect on national stock markets.

\section{Results of Model III}

In Model III, the exchange rate is removed and the return on the world market portfolio is left in the model. The shares of factors on return volatility are reported in Table 6. After removing the exchange rate, the contributions of world market to returns volatility decreased marginally to $1.6 \%$, down from
$1.7 \%$ in Model II. By excluding the exchange rate in Model III, the authors of the present study wanted to see if the interest rate parity (IRP) holds in emerging markets. In accordance with IRP, the contribution of exchange rate to return volatility would be attributed to the inflation rate and the interest rate. ${ }^{13}$ However, a very small increase in the factor loading of the inflation rate from 2.98 to 3.03 and a very small decrease in the factor loading of the real interest rate from 3.68 to 3.67 is found.

The results point to major differences between the emerging markets and the developed markets. In the developed markets returns volatility is explained by fluctuations in the fundamental variable that is, the dividend yield. On the other hand, the large impact of lagged return on the market index in emerging markets suggests predictability of returns in these

\footnotetext{
${ }^{13}$ According to IRP, exchange rate fluctuations are determined by the interest rate differential between the home country and the foreign country.
} 
Table 6. Variance decomposition of monthly returns on MSCI composite index for sample countries - Model III

\begin{tabular}{|c|c|c|c|c|c|c|}
\hline Country & $\begin{array}{l}\text { Standard } \\
\text { error }\end{array}$ & $\begin{array}{l}\text { Dividend } \\
\text { yield }\end{array}$ & $\begin{array}{l}\text { Inflation } \\
\text { rate }\end{array}$ & $\begin{array}{l}\text { Real } \\
\text { interest } \\
\text { rate }\end{array}$ & $\begin{array}{l}\text { Return on } \\
\text { national } \\
\text { MSCI index }\end{array}$ & $\begin{array}{l}\text { Return on } \\
\text { MSCI } \\
\text { world index }\end{array}$ \\
\hline \multicolumn{7}{|l|}{ Emerging Markets } \\
\hline Argentina & 0.1015 & 66.2112 & 7.0810 & 0.5190 & 25.3269 & 0.8619 \\
\hline Brazil & 0.1103 & 9.8687 & 10.4565 & 8.1706 & 71.1941 & 0.3101 \\
\hline Chile & 0.0667 & 45.2892 & 7.1570 & 4.3468 & 42.8710 & 0.3360 \\
\hline Mexico & 0.0890 & 52.0963 & 0.6864 & 0.8787 & 43.2944 & 3.0442 \\
\hline \multicolumn{7}{|l|}{ Eastern Europe } \\
\hline Czech Republic & 0.0867 & 4.7186 & 1.3781 & 3.8529 & 88.4699 & 1.5804 \\
\hline Hungary & 0.1234 & 21.4210 & 0.7170 & 10.1717 & 66.8203 & 0.8701 \\
\hline Poland & 0.1199 & 23.9511 & 0.9138 & 2.4197 & 71.9727 & 0.7427 \\
\hline Russia & 0.2343 & 5.3146 & 8.0745 & 9.6389 & 73.9533 & 3.0187 \\
\hline Turkey & 0.1749 & 52.7624 & 1.3833 & 5.9302 & 37.3862 & 2.5379 \\
\hline \multicolumn{7}{|l|}{ South East Asia } \\
\hline Hong Kong & 0.0855 & 77.9015 & 0.0914 & 2.0672 & 16.2670 & 3.6730 \\
\hline Indonesia & 0.1183 & 34.5784 & 1.4487 & 1.1554 & 59.5600 & 3.2575 \\
\hline Korea & 0.1082 & 60.4830 & 4.4664 & 1.0862 & 33.5398 & 0.4247 \\
\hline Malaysia & 0.1112 & 71.2449 & 4.6588 & 3.8786 & 18.2221 & 1.9956 \\
\hline Philippines & 0.0899 & 26.6033 & 1.3631 & 0.7878 & 70.4585 & 0.7873 \\
\hline Singapore & 0.0695 & 53.0563 & 0.4625 & 3.0504 & 43.1119 & 0.3188 \\
\hline Taiwan & 0.0916 & 69.7378 & 0.3436 & 0.5058 & 27.0947 & 2.3182 \\
\hline Thailand & 0.1233 & 48.3581 & 0.8217 & 3.9854 & 46.1760 & 0.6588 \\
\hline \multicolumn{7}{|l|}{ Developed Markets } \\
\hline Japan & 0.0608 & 93.2405 & 0.0057 & 0.2315 & 6.3159 & 0.2065 \\
\hline U.S. & 0.0448 & 84.1785 & 0.4477 & 0.1258 & 15.2325 & 0.0155 \\
\hline \multicolumn{7}{|l|}{ Average } \\
\hline Emerging Markets & & 42.5645 & 3.0296 & 3.6733 & 49.1599 & 1.5727 \\
\hline $\begin{array}{l}\text { Developed Markets } \\
\text { (Japan and the U.S.) }\end{array}$ & & 88.7095 & 0.2267 & 0.1787 & 10.7742 & 0.1110 \\
\hline
\end{tabular}

Note: Model III is Model II where the exchange rate is excluded in the estimations to eliminate the effect of currency crises.

markets. Thus, they would not be weak-form efficient. Hong Kong emerges as the only one among the emerging market countries that demonstrate volatility characteristics similar to that of the developed markets. Stock markets in transition countries such as the Russian Federation and the Czech Republic demonstrate the largest differences compared to developed markets as well as other emerging markets. Economic policies such as the exchange rate and monetary policies rather than the market fundamentals significantly influence the stock market return volatility in transaction countries.

\section{Conclusion}

This study estimates the contributions of fundamental factors as well as additional factors that represent monetary and fiscal policy to the variation in stock returns for the 17 emerging and two developed markets using a VAR model.
Using a comprehensive model that includes dividend yield, exchange rate, real interest rate, inflation rate and the movements in the world market index, the average contribution of dividend yields to return volatility in emerging markets is about $43 \%$ while it is about $90 \%$ in the two developed markets, namely the USA and Japan. Lagged returns account for about $46 \%$ of returns volatility in emerging markets. Short-term real interest rates account for about 3.7\% of returns volatility and exchange rates contribute about $3.2 \%$. World market index contributes about $1.6 \%$ to returns volatility. While dividend yield contributions to stock market volatility in the emerging markets is about $42 \%$ it accounts for $84 \%$ and $93 \%$ of the returns volatility in the USA and Japan respectively. Lagged returns are about $15 \%$ for the USA and $6 \%$ for Japan. The effects of other factors are insignificant for the US and Japanese stock market returns.

Dividend yield remains an important source of stock return fluctuations as predicted by the efficient 
market hypothesis. Lagged fluctuations in stock returns were other major factors accounting for the variance of stock market returns. Fluctuations in the world market portfolio do not significantly affect returns volatility in emerging markets. This finding supports the segmented markets argument about emerging markets. The decomposition of return variances indicates that the effects of variables that are influenced by monetary and trade policies such as the interest rates and the exchange rate have varying contributions as determinants of return volatility in emerging markets. However, these factors have no effect on returns in developed markets.

Significant differences exist between the developed markets and the emerging markets in terms of the sources of return volatility. Comparison of the sources of return volatility in emerging markets to the USA and Japan demonstrate major differences in the effects of fundamental variables. While fundamental variables like the dividend yield are the main sources of return volatility in developed markets as the theory would predict, the contributions of these variables to return volatility in emerging markets are much less, about one-half of the contributions in developed markets. Large factor loadings of lagged returns as a source of return volatility imply predictability and persistence in emerging markets. Hong Kong, among the emerging countries, is the only country with volatility characteristics similar to developed countries. However, in transition countries, returns volatility is highly influenced by monetary and exchange rate policies to a large extent. Therefore, these countries must be considered as the least developed emerging financial markets.

We do not find significant contribution of world markets on returns volatility in emerging stock markets in the sample period contrary to Bekaert and Harvey (1997). Similar to the present results, in their analysis of the South Korean stock market, Choe et al. (1999) did not find any impact of the foreign investors resulting in big fluctuations in returns during and after the 1997 crisis.

\section{Acknowledgements}

An earlier version of this paper was presented at the 52nd Annual Meeting of the Midwest Finance Conference in St Louis, Missouri. We would like to thank Gulnur Muradoglu, Vivian Fernandez and participants at the conference for their comments and recommendations.

\section{References}

Bekaert G. and Harvey, C. R. (1995) Time-varying world market integration, Journal of Finance, 50, 403-44.

Bekaert, G. and Harvey, C. R. (1997) Emerging equity market volatility, Journal of Financial Economics, 43, 29-77.

Breeden, D. T., Gibbons, M. R. and Litzenberger, R. H. (1989) Empirical tests of consumption oriented CAPM, The Journal of Finance, 44, 231-62.

Campbell, J. Y. (1987) Stock returns and the term structure, Journal of Financial Economics, 18, 373-400.

Campbell, J. Y. (1991) A variance decomposition for stock returns, The Economic Journal, 101, 157-79.

Campbell, J. Y. and Mankiw, N. G. (1989) Consumption, income and interest rates: reinterpreting the time-series evidence, in NBER Macroeconomics Annual 89 (Eds) O. J. Blanchard and S. Fischer, MIT Press, Cambridge, MA, pp. 185-216.

Campbell, J. Y. and Shiller, R. J. (1988) Stock prices, earnings and expected dividends, The Journal of Finance, 43, 661-79.

Caner, S. and Önder, Z. (1998) Sources of fluctuations in stock returns in the Istanbul stock exchange, Boğazici Journal: Review of Social, Economic and Administrative Studies, 12, 99-118.

Chakrabarti, R. and Roll, R. (2000) East Asia and Europe during the 1997 Asian Collapse: a clinical study of a financial crisis, Journal of Financial Markets, 5, 1-30.

Chen, N., Roll, R. and Ross, S. A. (1986) Economic forces and the stock market, Journal of Business, 56, 383-403.

Choe, H., Kho, B. and Stulz, R. (1999) Do foreign investors destabilize stock markets? The Korean experience in 1997, Journal of Financial Economics, 54, 227-64.

Chowdhry, B. and Goyal, A. (2000) Understanding the financial crisis in Asia, Pacific-Basin Finance Journal, 8, 135-52.

De Santis, G. and Imrahoroglu, S. (1997) Stock returns and volatility in emerging financial markets, Journal of International Money and Finance, 16, 561-79.

Fama, E. F. and French, K. R. (1988) Dividend yields and expected stock returns, Journal of Financial Economics, 22, 3-26.

Granger, W. J. C., Huang, B. N. and Yang, C. W. (2000) A bivariate causality between stock prices and exchange rate: evidence from recent Asia Flu, The Quarterly Review of Economics and Finance, 40, 337-54.

Harvey, C. R. (1995) Predictable risks and returns in emerging markets, Review of Financial Studies, 8, $773-816$

Harvey, R. C., Solnik, B. and Zhou, G. (2002) What determines expected international asset returns?, Annals of Economics and Finance, 3, 249-98.

Korajczyk, R. A. (1996) A measure of stock market integration for developed and emerging markets, World Bank Economic Review, 10, 267-89.

Long, J. B., Jr. and Plosser, C. I. (1983) Real business cycles, Journal of Political Economy, 91, 39-69.

Lucas, R. (1978) Asset prices in an exchange economy, Econometrica, 46, 1429-44.

Mankiw, N. G. and Zeldes, P. S. (1991) Consumption of stockholders and non-stockholders, Journal of Financial Economics, 29, 97-112. 
Appendix

Table A1. Correlations

\begin{tabular}{|c|c|c|c|c|c|}
\hline & $\begin{array}{l}\text { Market } \\
\text { return }\end{array}$ & $\begin{array}{l}\text { Dividend } \\
\text { yield }\end{array}$ & $\begin{array}{l}\text { Growth } \\
\text { rate }\end{array}$ & $\begin{array}{l}\text { Exchange } \\
\text { rate }\end{array}$ & $\begin{array}{l}\text { Inflation } \\
\text { rate }\end{array}$ \\
\hline \multicolumn{6}{|l|}{ Argentina } \\
\hline Dividend yield & -0.2171 & & & & \\
\hline Growth rate & -0.0377 & $7 \quad 0.0051$ & & & \\
\hline Exchange rate & -0.0250 & -0.0501 & -0.0499 & & \\
\hline Inflation rate & 0.1105 & $5-0.1049$ & -0.0457 & 0.1057 & \\
\hline Real interest rate & -0.1082 & $2 \quad 0.1699$ & 0.0555 & -0.1075 & -0.9676 \\
\hline \multicolumn{6}{|l|}{ Brazil } \\
\hline Dividend yield & -0.0024 & & & & \\
\hline Growth rate & 0.1782 & $2-0.0049$ & & & \\
\hline Exchange rate & 0.0829 & 0.0915 & -0.0244 & & \\
\hline Inflation rate & 0.2011 & 0.2049 & 0.1112 & 0.0133 & \\
\hline Real interest rate & -0.2137 & -0.3757 & -0.1700 & 0.0453 & -0.8003 \\
\hline \multicolumn{6}{|l|}{ Chile } \\
\hline Dividend yield & -0.1926 & & & & \\
\hline Growth rate & 0.2514 & $4-0.0375$ & & & \\
\hline Exchange rate & -0.2537 & $7 \quad 0.0781$ & -0.0608 & & \\
\hline Inflation rate & 0.1158 & 0.1366 & 0.2324 & 0.0624 & \\
\hline Real interest rate & -0.1423 & $3-0.1221$ & -0.2312 & -0.0636 & -0.9912 \\
\hline \multicolumn{6}{|l|}{ Mexico } \\
\hline Dividend yield & -0.2869 & & & & \\
\hline Growth rate & 0.1813 & $3-0.2108$ & & & \\
\hline Exchange rate & -0.2757 & $7 \quad 0.2520$ & -0.0099 & & \\
\hline Inflation rate & 0.1984 & $4 \quad 0.2648$ & 0.1389 & -0.0787 & \\
\hline Real interest rate & -0.0753 & $3 \quad 0.6175$ & -0.2418 & 0.2522 & -0.2172 \\
\hline \multicolumn{6}{|l|}{ Czech Republic } \\
\hline Dividend yield & -0.1398 & & & & \\
\hline Growth rate & -0.0344 & $4-0.0022$ & & & \\
\hline Exchange rate & -0.1460 & -0.0280 & -0.0160 & & \\
\hline Inflation rate & -0.0088 & -0.1997 & 0.1127 & -0.0546 & \\
\hline Real interest rate & -0.0456 & $5 \quad 0.1638$ & -0.1471 & 0.0329 & -0.8379 \\
\hline \multicolumn{6}{|l|}{ Hungary } \\
\hline Dividend yield & -0.0134 & & & & \\
\hline Growth rate & 0.0037 & $7-0.0037$ & & & \\
\hline Exchange rate & 0.0814 & $4-0.0371$ & 0.1319 & & \\
\hline Inflation rate & 0.0901 & 0.2541 & 0.3369 & 0.1032 & \\
\hline Real interest rate & 0.0102 & $2 \quad 0.1210$ & -0.3379 & -0.1389 & -0.8847 \\
\hline \multicolumn{6}{|l|}{ Poland } \\
\hline Dividend yield & 0.0766 & & & & \\
\hline Growth rate & 0.0117 & $7-0.0130$ & & & \\
\hline Exchange rate & -0.1825 & $5 \quad 0.0463$ & 0.1130 & & \\
\hline Inflation rate & -0.1536 & $5-0.1182$ & 0.1261 & 0.1958 & \\
\hline Real interest rate & 0.0689 & 0.1857 & -0.1389 & -0.2542 & -0.9111 \\
\hline \multicolumn{6}{|l|}{ Russia } \\
\hline Dividend yield & 0.1738 & & & & \\
\hline Growth rate & 0.4354 & $4-0.1073$ & & & \\
\hline Exchange rate & -0.5018 & -0.1120 & -0.1659 & & \\
\hline Inflation rate & -0.0661 & -0.3051 & -0.0194 & 0.2225 & \\
\hline Real interest rate & -0.0525 & $5 \quad 0.3976$ & -0.1994 & -0.0453 & -0.8162 \\
\hline \multicolumn{6}{|l|}{ Turkey } \\
\hline Dividend yield & -0.1437 & & & & \\
\hline Growth rate & 0.0220 & 0.0387 & & & \\
\hline Exchange rate & -0.0469 & -0.0119 & -0.0050 & & \\
\hline Inflation rate & 0.0997 & $7 \quad 0.0438$ & -0.0980 & 0.5212 & \\
\hline Real interest rate & -0.1454 & $4 \quad 0.2182$ & 0.0298 & -0.3127 & -0.7096 \\
\hline
\end{tabular}

(continued)
Table A1. Continued

Market Dividend Growth Exchange Inflation return yield rate rate rate

\begin{tabular}{|c|c|c|c|c|c|}
\hline \multicolumn{6}{|l|}{ Hong Kong } \\
\hline Dividend yield & -0.1079 & & & & \\
\hline Growth rate & 0.0520 & -0.1116 & & & \\
\hline Exchange rate & -0.0639 & -0.0733 & 0.0206 & & \\
\hline Inflation rate & -0.0124 & 0.3541 & 0.1904 & -0.1001 & \\
\hline Real interest rate & -0.0502 & -0.2270 & -0.2298 & 0.0802 & -0.9755 \\
\hline \multicolumn{6}{|l|}{ Indonesia } \\
\hline Dividend yield & -0.0167 & & & & \\
\hline Growth rate & -0.0852 & -0.1764 & & & \\
\hline Exchange rate & 0.0535 & -0.0170 & -0.0420 & & \\
\hline Inflation rate & 0.0856 & 0.0687 & -0.1832 & 0.7724 & \\
\hline Real interest rate & -0.0706 & 0.0358 & 0.1499 & -0.7518 & -0.9712 \\
\hline \multicolumn{6}{|l|}{ Korea } \\
\hline Dividend yield & -0.3819 & & & & \\
\hline Growth rate & 0.0398 & -0.1624 & & & \\
\hline Exchange rate & -0.0505 & 0.4411 & -0.1304 & & \\
\hline Inflatior & 0.2062 & 0.1876 & -0.1063 & 0.5640 & \\
\hline Real interest rate & -0.2771 & -0.0937 & 0.0524 & -0.5399 & -0.9366 \\
\hline \multicolumn{6}{|l|}{ Malaysia } \\
\hline Dividend yield & -0.2185 & & & & \\
\hline rowth rate & -0.1594 & -0.1283 & & & \\
\hline xchange rate & -0.3798 & -0.0414 & 0.3066 & & \\
\hline Infl & -0.1502 & -0.1799 & 0.0000 & 0.1187 & \\
\hline Real interest rate & 0.1118 & 0.2393 & -0.0284 & -0.1100 & -0.9911 \\
\hline \multicolumn{6}{|l|}{ Philippines } \\
\hline Dividend yield & -0.1751 & & & & \\
\hline rate & -0.0182 & 0.0764 & & & \\
\hline rate & -0.1682 & 0.2450 & 0.0615 & & \\
\hline Inflatio & 0.0621 & 0.1407 & -0.0656 & 0.0635 & \\
\hline Real interest rate & -0.0550 & -0.0619 & 0.0647 & -0.0638 & -0.979 \\
\hline \multicolumn{6}{|l|}{ Singapore } \\
\hline Dividend yield & -0.2586 & & & & \\
\hline th rate & 0.0608 & -0.0281 & & & \\
\hline cate & -0.3863 & 0.1481 & -0.0700 & & \\
\hline Inflation rate & -0.1920 & 0.0034 & 0.0210 & -0.1312 & \\
\hline Real interest rate & 0.1766 & 0.0225 & -0.0190 & 0.1316 & -0.9960 \\
\hline \multicolumn{6}{|l|}{ Taiwan } \\
\hline ividend yield & -0.2291 & & & & \\
\hline Growth rate & 0.1754 & -0.0918 & & & \\
\hline Exchange rate & -0.3010 & 0.1020 & -0.1763 & & \\
\hline Inflati & -0.0674 & 0.0182 & -0.0386 & 0.4858 & \\
\hline Real interest rate & 0.0677 & 0.0014 & 0.0400 & -0.4881 & -0.9972 \\
\hline \multicolumn{6}{|l|}{ Thailand } \\
\hline end yield & -0.1715 & & & & \\
\hline t & 0.0605 & -0 . & & & \\
\hline Exchange rate & -0.0983 & 0.1346 & -0.0312 & & \\
\hline Inflatio & -0.1184 & 0.2015 & -0.1604 & 0.2774 & \\
\hline Real interest rate & 0.0522 & 0.0827 & 0.1103 & -0.2459 & -0.923 \\
\hline \multicolumn{6}{|l|}{ Japan } \\
\hline eld & -0.1404 & & & & \\
\hline Growth rate & -0.1000 & -0.1287 & & & \\
\hline Exchan & -0.0297 & -0.0675 & -0.1553 & & \\
\hline Inflatio & -0.0395 & -0.2002 & 0.1686 & 0.0456 & \\
\hline Real interest rate & -0.0556 & 0.0358 & -0.1461 & -0.1346 & -0.6896 \\
\hline \multicolumn{6}{|l|}{ USA } \\
\hline Dividend yield & -0.0261 & & & & \\
\hline Growth rate & -0.1775 & -0.1269 & & & \\
\hline e rate & 0.0300 & -0.2114 & 0.0835 & & \\
\hline rate & -0.0320 & -0.0076 & 0.0694 & -0.0308 & \\
\hline Real interest rate & 0.0383 & 0.1004 & -0.1106 & 0.0203 & -0.9817 \\
\hline
\end{tabular}

